\title{
2.1 Graffiti Murals as Social Innovation. An Example of a Cooperative and Planned Process of Urban Development in Aachen, Germany
}

\author{
Christopher D. HILMER \\ RWTH Aachen University
}

\section{Introduction: Cities and their graffiti dilemma}

"Illegal graffiti became a monument" was a headline in a local Aachen newspaper in 2011 (DPA 2011). Since then two more wall paintings of the graffiti pioneer Klaus PAIER have become official monuments in the city center of Aachen. A group of dedicated local residents initiated the conservation of the graffiti, these unauthorized paintings in the public space, and throughout Germany it is a unique strategy of urban development. Graffiti and street $\operatorname{art}^{1}$ are becoming more and more established as instruments for urban design, management, and planning. "Street art's gentrification and commodification (...)" are the result of a progress shaped by tourism offices and city marketing strategies (BENGSTEN 2014, p. 172). By implementing and connecting images of graffiti and street art with a 'cool' lifestyle they hope to attract tourists, investments, and young talents, especially in the field of the creative industries (cf. SCHACTER 2014).

The "(...) re-evaluation of graffiti in the light of the importance of creativity to the post-industrial economy (...)" was preceded by and is still subjected to a strict and oppressive one-sided policy against graffiti and its actors in many German cities (McAuliffe 2012, p. 190). Soon after the beginning of the graffiti (style writing)

\footnotetext{
For a broad understanding of the terminology: Graffiti and street art are (more or less) NOT permitted artistic expressions placed on public surfaces. In this article the term 'graffiti' refers to the typographic andcalligraphic style writing which originated in the 1970's in New York City. Street art is understood to be the more iconographic andfigure-orientated movement which has a higher range of affiliated artistic expressions and is not as "limited" to letters, spray cans and hip hop. There are numerous definitions and understandings of the terms 'graffiti' and 'street art', and researchers and scientific networks like urbancreativity.org and wallandspace.org are striving for academic legitimacy. For a better understanding of the terms and the current state of scholarship on graffiti and street art see the article by J.I. Ross (2017).
} 
phenomenon in the late 1960's in Philadelphia and in the 1970's in New York City (cf. Kimvall 2014, p. 37), city officials considered graffiti as a whole a menace to society. City authorities established a zero tolerance policy towards graffiti, its actors and its urban context. Graffiti was framed as something 'out of place', something that did not belong to the western civilized world, but that one would expect to find in uncivilized cities of the Third World (cf. CRESSwELl 1996, p. 42). The wars on graffiti and the new military urbanism (IvESON 2010) also reached Europe and led to the establishment of local anti-graffiti agencies and harsh law enforcement. Seen from this perspective graffiti constitutes a great problem for community life, one that creates socio-economic damage of up to 500 million euros each year in cleaning costs in urban areas of Germany (DPA 2010). Looking at the situation from a dichotomous perspective: On the one hand, visionaries of the art market declared a graffito, a wall painting which was placed without permission on public walls, to be one of Britain's best-loved artworks of all time (Hughes 2017). And on the other hand, city officials are very busy in stripping unauthorized wall paintings from the urban landscape with enormous costs each year.

Alternative and participative initiatives are rethinking this dilemma of urban development. Together with graffitists they are working on transforming this problem into an endeavor that is particularly promising for building more social, creative, and sustainable communities. To understand and analyze this transformation as a strategic placement of graffiti in an urban context, I have interviewed and worked with actors who participate in governance arrangements of "doing graffiti". Here, I will focus on three different practices: commissional graffiti works, (self-)organized Halls of Fame, ${ }^{2}$ and graffiti workshops. These three practices are common worldwide and are based on socially innovative processes of arrangements, proceedings, and collaborations. Based on my research conducted in this area thus far, I have found that new proceedings and collaborations between a diverse range of actors have led to new solutions to the urban graffiti dilemma and could therefore be understood as a form of social innovation (referring to Moulaert 2005, 2010, Howaldt/Schwarz 2010a). In the following chapters, I will present my observations of 'new' graffiti murals and their local arrangements, briefly introduce my research design and progress, and present a graffiti workshop in Aachen as an example for a socially innovative process of urban development.

\section{Graffiti murals and their local arrangements}

Graffiti murals, the combination of the terms 'murals' or 'muralism' and 'graffiti' is a "(...) label for mural installations using aerosol paints (spray paint) and techniques of contemporary aerosol art” (Healey 2016, p. 9). The mural art movement is an

2 In the graffiti world the term 'Hall of Fame' is used for walls and areas where it is legal to paint and present one's own graffiti styles. For more information see, e.g., the "glossary of glossaries" by Kimvall 2014, p. 203. 
architectural art form that incorporates open wall spaces such as fire walls, gables and sculptural elements (KUZDAS 1994, p. 18). In West Germany, the practice of permitting wall paintings in the public space started in the 1970s. At first the dominating themes were eco-political images and messages. The first official mural in a West German public space was Ben Wargin's "Weltbaum - Grün ist Leben/ World tree - Life is green", made in Berlin in 1975 (KuzDas 1994, p. 4). Since the beginning of the $21^{\text {st }}$ century there has been a rapid increase of huge wall paintings in cities worldwide. This development of at times massive, multi-storey wall paintings is a complex process of mixing traditional forms and ideas of the mural art movement with new techniques and themes of contemporary aerosol art, in particular elements of (style writing) graffiti and street art. "Diverse methods of painting walls have especially strengthened new muralism (...)", and some authors and artists proclaim that the "Old muralismo is dead! Long live the new muralismo!"' (Besser 2010, p. 14).

Within the scope of my research, I will take a closer look at wall paintings that belong to this "new muralismo" and focus on the typographic and calligraphic elements. The following criteria describe my observations of 'new' graffiti murals in the public space and illustrate the case objects of my study:

- Typographic elements of style writing and hip hop graffiti

- Aerosol art, predominantly using spray cans

- Commissioned in the 21 st century

- \#graffiti mural, featuring a hashtag (\#), @ or website

- Placed accessibly in the public space

- Of a certain size, meaning larger than life (by using a lifting platform, scaffold etc., cf. AbArca 2016, p. 61)

The mural in Figure 1 shows all the criteria of new graffiti muralism. The names of the graffiti muralists can be found in the top part of the mural. These are typical wildstyle masterpieces, ${ }^{3}$ which are characteristic elements of the graffiti writing culture. Most passers-by can neither read nor decipher the names, and there is the possibility that similar masterpieces are placed in the public space without permission. The cartoonish theme of the mural (based on the animated movie "Cars") highlights the fact that the facade belongs to a local car dealer. The graffiti mural was spray-painted, placed accessibly in the public space, is more than five meters high, and was commissioned in 2014. The mural also provides the graffitists' web address at the bottom right-hand part of the mural.

\footnotetext{
3 In the graffiti world the term 'masterpiece' refers to " $(. .$.$) an artistic and complex form of$ writing featuring stylized letters, color, depth, and a variety of designs." The term 'wildstyle' refers to a "(...) complex writing style characterized by its angular interlocking letters." (See the "glossary of glossaries" by Kimvall 2014, p. 213.)
} 
Figure 1: Example of a 'new' graffiti mural in Aachen - KEAS \& COKY (Photo: Hilmer 2017)

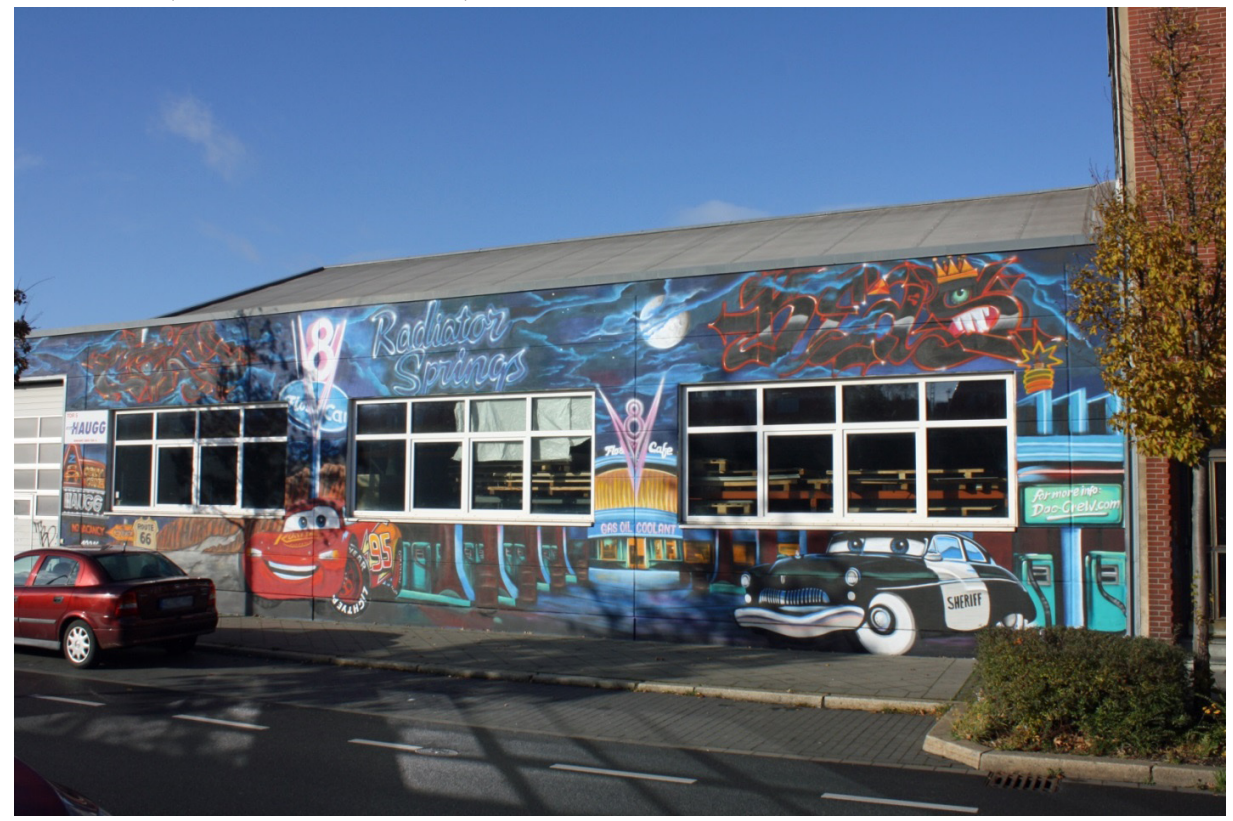

An example of a commissional work that combines all of the criteria of a 'new' graffiti mural. The graffitists KEAS and COKY painted a big facade of a local car dealer with their wildstyle masterpieces and a Pixar-/Disney-inspired cartoon. Established graffitists known city-wide offer their services as outdoor facade designers. Their handicraft is a particularly popular form of "protection of graffiti by graffiti" (HiLmer 2013).

For my ongoing research, it is crucial to understand that murals " (...) are not merely seen as works of art, but rather are objects which fulfill a certain social, cultural, political and economic purpose, as well as their own life span." (RAPP 2012, p. 70). Their purposes are reified through collaboration processes, through social, cultural, and economic coordination, and through balancing the different actors' motivations and proposals. My understanding of social innovation is based on HowALDT and SchwARz's definition. The authors define social innovation as a "(...) reconfiguration of social practices in certain fields of action with the aim of better solving problems or needs (...) than it is possible on the basis of established practices" (HowALDT/Schwarz 2010b). The aim of "better solving" could be applied by using and recognizing the creative potential of actors of the street art and graffiti world, for example, and reducing the repression against them. HowALDT and SchwARz claim that 'the new' cannot be found in the medium of technological artifacts, but on the level of social practices, such as governing, organizing, supplying, consuming, through partnership, and negotiation 
(Howaldt/Schwarz 2010b). The multidimensional practices of "doing graffiti" which I focus on here, namely commissional work of graffitists, (self-)organized Halls of Fame, and graffiti workshops, are characterized by a strong local embeddedness. My presupposition is that graffiti murals rely to a certain degree on local arrangements. I will refer to this local specificity as a graffiti spot.

\section{Research design: The graffiti-spot analysis}

Cultural and urban geographical literature and research related to aspects of graffiti and street art pose inter- and transdisciplinary questions and employ multi-methodical approaches (cf. Dickens 2009, Kramer 2010, McAuliffe 2012, BLOCh 2012). In order to develop an understanding of the socially innovative processes of establishing, legalizing, and integrating graffiti murals into the visual appearance of a city, the starting point of my field work are in situ single graffiti murals in cities. My selection of the murals is based on incremental sampling (Fig.2). After selecting and classifying the graffiti murals on the basis of the criteria of new graffiti muralism (see Chapter 2), I try to

Figure 2: Research progress: Incremental sampling of graffiti-murals (HILMER 2017)

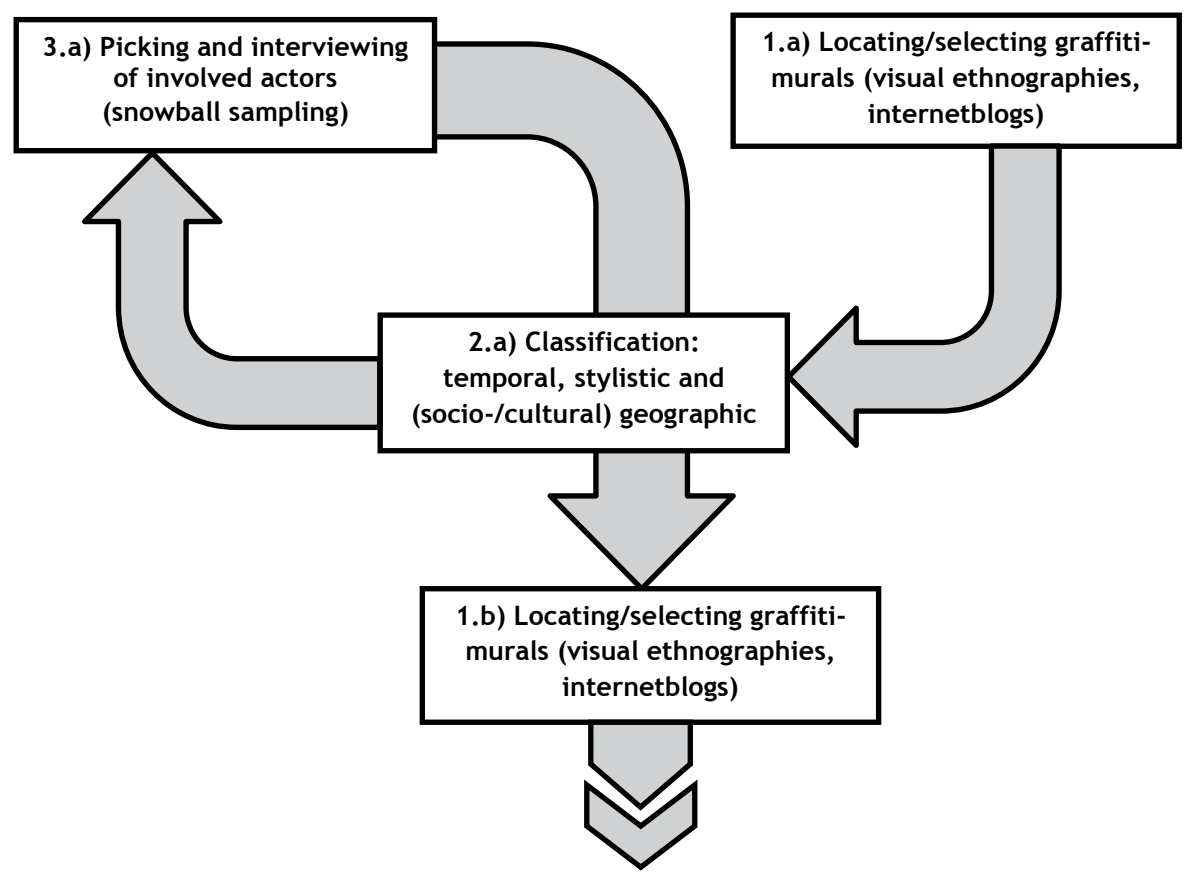


identify which (group of) actors were involved in the placement of the single murals in the public space. In order to recreate and interpret the different stages of development in the dynamic process of collaboration and working together, those actors involved in the development of the selected graffiti murals are interviewed by semi-open and guided interviews. After the interviews with the involved actors of the first graffiti mural I (re-) classify and (re-)interpret the graffiti mural once more and continue with another graffiti mural. Theoretically, the sampling would be complete once all of the actors involved in the new graffiti murals have been identified and interviewed.

The spatial starting point for my analysis of the planned and coordinated placement of a graffiti mural is the neighborhood, the smallest scale for practicing urban development. Area-based community building processes are "(...) the loci and drivers of social innovation (...)” (Moulaert 2010, p. 7) and offer “(...) a 'window' into wider scalar processes" (GonZÁLEZ et al. 2010, p. 51). My research model (Fig. 3) is based on BAYER's preliminary consideration that " $(. .$.$) the social phenomenon graffiti is the result$ of the interactions of three bigger groups of actors (...)" (BAYER et al 2006, p. 6). I have extended BAYER's model by including the group "audience", because new practices such as geotagging and blogging about graffiti murals have a strong impact on the framing of graffiti and also on cities' communication campaigns and neighborhood management processes. The graffiti spot is meant to be a unilateral space-and-time-correlated interaction (motivated by the single actors, local settings, local graffiti communities and their 'battles') embedded in a field of constant and multilateral interactions (laws, norms, 'unwritten rules of the graffiti writing culture') of all four groups of actors. Those dynamic interactions in the urban policy field, which include the actors' roles, interests, goals, and motivations, form the basis of my research analysis. In addition, I will be using the visual ethnographies of at least 50 Halls of Fame that I have visited and painted in situ. Furthermore, I have conducted serendipitous interviews with the people I met at the Halls of Fame while I was painting. This allowed me to experience the atmosphere around "legalized" graffiti and the spatial ordering of the reserved graffiti of different cities.

\section{Graffiti-project: "Aachen-Nord shows its colors"}

Overall, the city of Aachen can be described as conservative with an oppressive atmosphere towards graffiti. The city does not have an official Hall of Fame and uses specific anti-graffiti practices. Nevertheless, there are neighborhoods in Aachen in which graffiti and practices associated with graffiti are being re-evaluated. One neighborhood in particular needs mentioning, where a graffiti project was partly coordinated by the local neighborhood office and was supported with public funds. This illustrates that local authorities in Aachen are taking a new stand towards actors of the graffiti world and that they are parting from the familiar path of a one-sided zero tolerance policy. This neighborhood is Aachen-Nord. 
Figure 3: Dynamics in the development of the graffiti spot

(Source: Modified after BAYER 2006, p. 6)

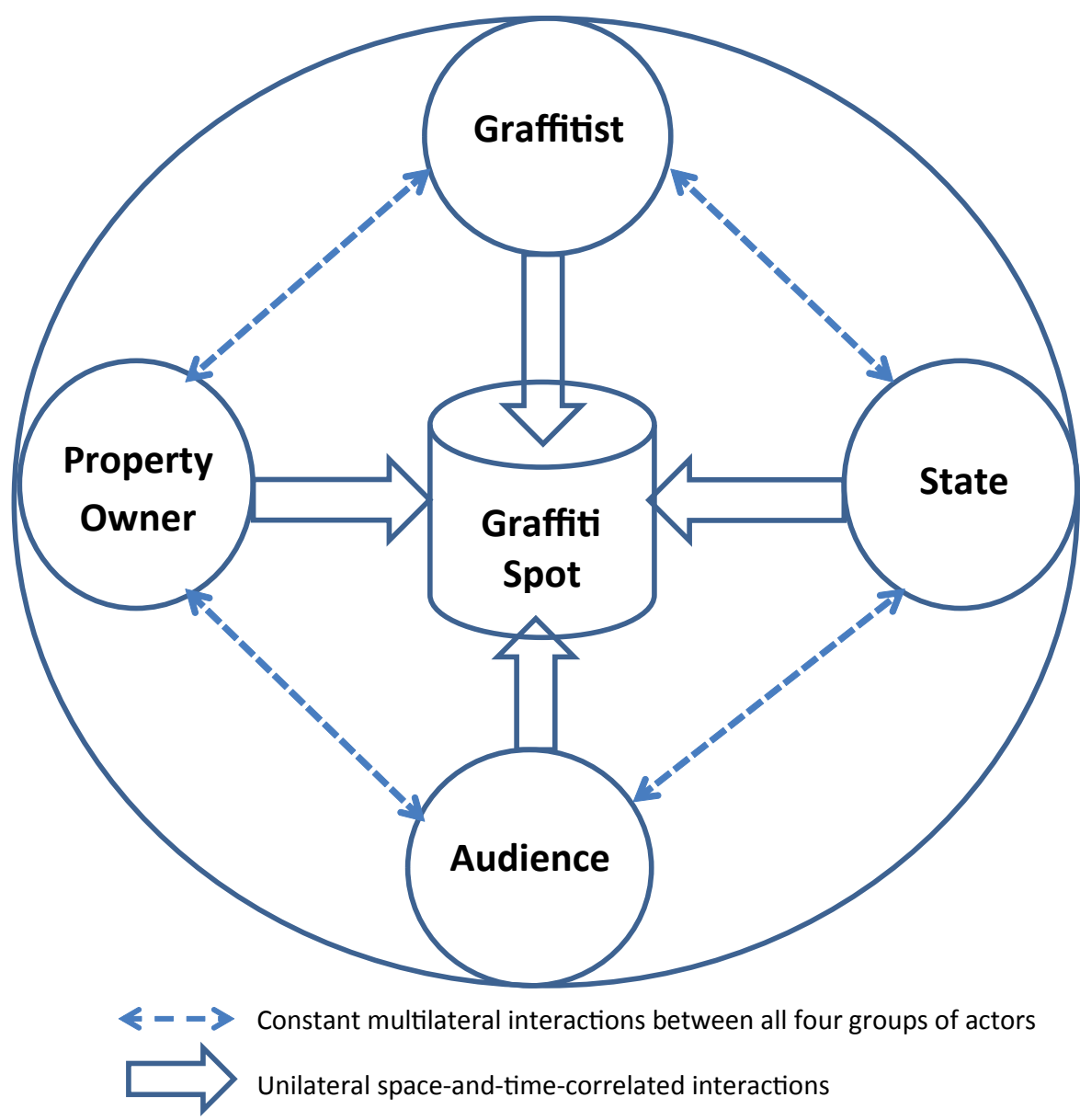

Aachen-Nord is regarded as a socially and economically disadvantaged and deprived neighborhood of Aachen. Following the typical path of deindustrialization of an old working class neighborhood, this part of Aachen is now characterized by the highest number of unemployment and disadvantaged groups receiving state aid (CITY OF AACHEN 2017a). The graffiti project "Aachen-Nord zeigt Farbe" (Aachen-Nord shows its colors) took place in 2013 and was a planned and coordinated campaign run by young and old graffitists, a neighborhood office, young residents, the "Aachener Kunstroute" (art event collective/initiative), and a local car dealer. It was the first time that those actors worked together as a team on one and the same project. The combination of a 
Figure 4: "Aachen-Nord zeigt Farbe/ Aachen-Nord shows its colors" (City of Aachen 2017b)

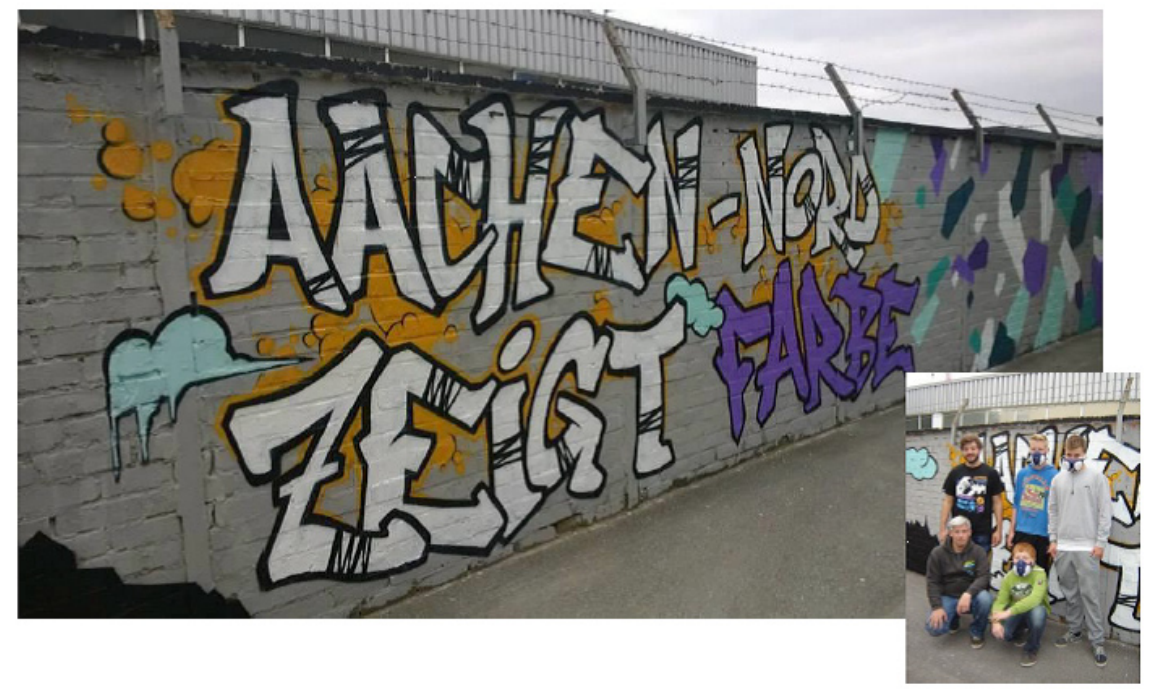

Final result of the graffiti-workshop instructed by the old-school graffiti-writer LAKE13. The name of the neighborhood (Aachen-Nord) is written in style.

graffiti workshop for young residents ( $>14$ years of age) and a live graffiti painting session by experienced graffitists and curators was especially remarkable. Old-school graffiti writers were able to show their styles with official media representatives of the city-wide art event "Aachener Kunstroute" in attendance. LAKE13, one of Aachen's well-known graffitists with more than 30 commissional wall paintings in the city, coordinated the workshop and the live painting. In terms of the effects for urban and regional development LAKE13 appreciated the chance to pass on his knowledge to the younger graffitists, including some unwritten rules of graffiti, crossing, respect for R.I.P. masterpieces, and the development of one's own style and handicraft. Because of the lack of a Hall of Fame in Aachen there is no other possibility to get in contact with one another and exchange knowledge in situ while painting together. Furthermore, LAKE13 considers live painting a good opportunity to present style writing to the public in the place where the art belongs (the streets) and to demonstrate that graffiti can also be seen as a handicraft.

The strategy of the key actors was to get those (young) local residents involved in this multidimensional process of urban development who had not participated in this kind of process before. They wanted to support local artists, foster a local city planning model, gain more attention for graffiti culture in general, and protect the area from 
vandalism. I understand this example of placing a graffiti mural in the public space as a kind of social innovation in MoulAERT's terms (2005: 1975 pp.), because the key actors fulfilled specific characteristics: (1) They included residents who could not or had not participated in processes of urban development before, (2) they overcame conservative forces, (3) they underlined the ethical position of one's right to the city, (4) they are path-dependent and contextual because they are based on a local city planning model that promotes urban development, and (5) they demonstrate changes taking place in the dynamics of social relations. Despite the fact that there is still an oppressive atmosphere towards graffiti in Aachen, the bottom-up movement initiated by dedicated local residents and initiatives is proof of changes happening in urban policy towards the framing of graffiti, and of changes in the visual appearance of Aachen owed to the establishment of a new graffiti muralism.

Figure 5: Results of the live painting session (Photo: HiLmer 2017)

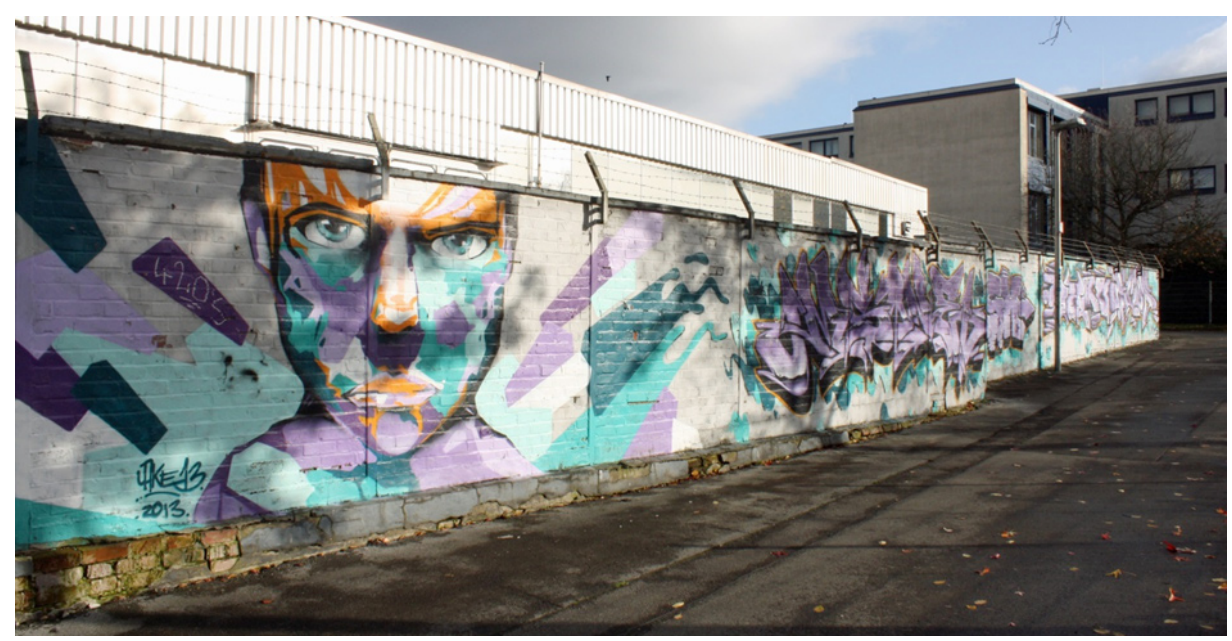

Final result of the live painting session with more than seven graffitists (more than $50 \mathrm{~m}$ long). A mix of iconographic elements ('characters') in the front and the typ-ical typographic elements of style writing in the back of the picture above. The characters are especially popular with audiences who are not able to decipher style writing. 


\section{References}

Abarca J. (2016), From street art to murals: what have we lost? Street Art \& Urban Creativity Scientific Journal 2(2), pp. 60-68.

Bayer M., Petermann S., \& Sackmann R. (2006), Graffiti in der sozialwissenschaftlichen Literatur. In: Sackmann, R. (ed.), Graffiti zwischen Kunst und Ärgernis. Empirische Studien zu einem städtischen Problem. Martin-Luther-Universität Halle-Wittenberg, Forschungsberichte des Instituts für Soziologie, pp. 4-11.

Bengsten P. (2014), The Street Art World. Lund, Almendros De Granada Press.

Besser J. (2010), Muralismo Morte: The Rebirth of Muralism in Contemporary Urban Art. Berlin, From here to fame.

BLoch S. (2012), The Illegal Face of Wall Space: Graffiti-murals on the Sunset Retaining Walls in Los Angeles. Radical History Review 113, pp. 111-126.

Cresswell T. (1996), In place/out of place: geography, ideology, and transgression. Minneapolis, MN, University of Minnesota Press.

GonzÁlez S., Moulaert F., \& Martinelli F. (2010), ALMOLIN: How to analyse social innovation at the local level? In: Moulaert F., Martinelli F., Swyngedouw E., \& GonzÁlez S. (eds.), Can neighbourhoods save the city? Community development and social innovation. London and New York, Routledge, pp. 49-67.

Healy G. A. (2016), American Indian Graffiti Muralism: Survivance and Geosemiotic Signposts in the American Cityscape. The University of Arizona (diss.).

HiLmer C. (2013), Graffiti als Handlungsfeld integrierter Stadtentwicklung: Vom kriminellen zum kommerziellen Hotspot - Eine Beispielanalyse anhand von Kiel (thesis).

Howaldt J., \& Schwarz M. (2010a), "Soziale Innovation” im Fokus: Skizze eines gesellschaftstheoretisch inspirierten Forschungskonzepts. Bielefeld, transcript.

Iveson K. (2010), The wars on graffiti and the new military urbanism. City 14(1-2), pp. 115-135.

Kimvall J. (2014), The G-Word: Virtuosity and Violation, Negotiating and Transforming Graffiti. Årsta, Dokument Press.

Kramer R. (2010), Painting with Permission: Legal Graffiti in New York City. Ethnography 11(2), pp. 235-253.

Kuzdas H.J. (1994), Muralart: Wandmalerei, wall painting, muralismo; Berlin, Los Angeles, México, D. F. Berlin, Schwarzkopf \& Schwarzkopf.

McAuliffe C. (2012), Graffiti or street art? Negotiating the Moral Geographies of the Creative City. Journal of Urban Affairs 34(2), pp. 189-206.

Moulaert F. (2010), Social innovation and community development: concepts, theories and challenges. In: Moulaert F., Martinelli F., Swyngedouw E., \& González S. (eds.), Can neighbourhoods save the city? Community development and social innovation. London and New York, Routledge, pp. 4-16.

Moulaert F., Martinelli F., Swyngedouw E., \& GonzÁlez S. (2005), Towards Alternative Model(s) of Local Innovation. Urban Studies 42(11), pp. 1969-1990.

Rapp M. (2012), Murals in Ulster: Symbol kultureller Revolution im nordischen Bürgerkrieg. kultuRRevolution. Zeitschrift für angewandte Diskurstheorie 61/62(1/2), pp. 69-75.

Ross J.I., Bengtsen P., Lennon J. F., Phillips J., \& Wilson J. Z. (2017), In search of academic legitimacy: The current state of scholarship on graffiti and street art. The Social Science Journal 54(4), pp. 411-419. 
Schacter R. 2014. The ugly truth: Street Art, Graffiti and the Creative City. Art \& the Public Sphere 3(2), pp. 161-176.

\section{Online References}

City of Aachen (2017a), Aachen-Nord: Ein Stadtteil im Wandel. http://www.aachen.de/de/stadt buerger/planen_bauen/stadtentwicklung/stadtviertel/aachennord/aachen-nord/index.html [Last accessed on 13-11-2017]

City of Aachen (2017b), Projekte der Stadtentwicklung - Rückblick auf bisherige Projekte: Wandgestaltung mit "Lake13" - Aachen-Nord zeigt Farbe! http://www.aachen.de/DE/ stadt_buerger/planen_bauen/_materialien_planen_bauen/stadtentwicklung/stadtviertel/ aachennord/vfonds/projekte/12_14/15_Aachen-Nord_zeigt_Farbe.pdf [Last accessed on 13-11-2017]

DPA (2010), Graffiti: Mehr als 200 Millionen Euro Schaden. Badische Zeitung. http://www. badische-zeitung.de/suedwest-1/graffiti-mehr-als-200-millionen-euro-schaden--29588101. $\mathrm{html}$ [Last accessed on 14-08-2017]

DPA (2011), Illegale Graffiti werden zum Denkmal. Aachener Zeitung. http://www.aachenerzeitung.de/lokales/region/illegale-graffiti-werden-zum-denkmal-1.379192 [Last accessed on 14-08-2017]

Howaldt J., \& Schwarz M. (2010b), Definition: Soziale Innovation. http://www.sfs.tu-dortmund. de/cms/de/Soziale_Innovation/index.html [Last accessed on 17-11-2017]

Hughes T. (2017), Constable? Turner? No, UK's favourite artwork is a Banksy: graffiti artist's creation Balloon Girl tops list of nation's best loved works. The Daily Mail. http://www. dailymail.co.uk/news/article-4730416/UK-s-favourite-artwork-Banksy.html?ITO=1490 [Last accessed on 14-08-2017]

\section{List of Figures}

Figure 1: Example of a 'new' graffiti-mural in Aachen - KEAS \& COKY .......... 64

Figure 2: Research progress: Incremental sampling of graffiti-murals ................65

Figure 3: Dynamics in the development of the graffiti-spot ...................................67

Figure 4: "Aachen-Nord zeigt Farbe/ Aachen-Nord shows its colors" "..................6 68

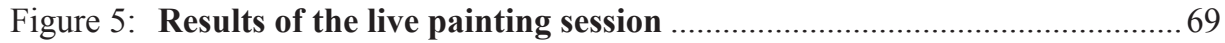


